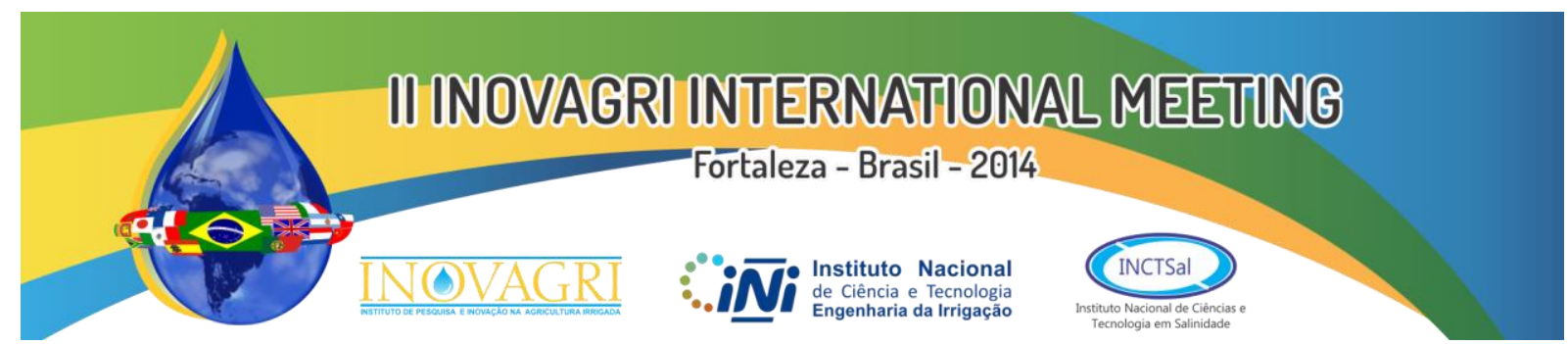

http://dx.doi.org/10.12702/ii.inovagri.2014-a044

\title{
HYDRO-ECONOMIC MODEL FOR THE ASSESSMENT OF WATER RESOURCES ALLOCATION AND AVAILABILITY IMPACTS ON AGRICULTURAL INCOME
}

\author{
M. de O. Torres ${ }^{1}$, M., L. Rodrigues ${ }^{2}$, J. M. Paz ${ }^{3}$
}

\begin{abstract}
The Buriti Vermelho experimental Basin (BHBV) is characterized by agricultural activities, seasonal water flow uncertainty and heterogeneous water allocation among rural farmers. In this context, this paper follows an interdisciplinary modeling approach that involves economics, hydrology and agronomy. The model developed is then used to evaluate the short-run impacts on agricultural income from changes on precipitation and irrigation water supply. The economic regional model follows a Positive Mathematical Programming approach which allows for the calibration of crop and farmer specific production functions. The hydrological model follows a water balance approach and yields water availability estimates on a proper time and spatial resolution. The two models are coupled together and calibrated with primary data collected in situ. Alternative temperature and precipitation regimes are simulated. Considering that the hydrologic characteristics of the region which, in normal years, guarantees a much higher supply of water for irrigation in the reservoirs relatively to demand and the fact that irrigated crops have a much heavier weight on the net revenue of the region than rainfed crops, a 5\% decrease in water availability would be accompanied by a decrease of only $1.2 \%$ in the regional net revenue. This percentage, however, would increase to $11 \%$ and $32 \%$ when water availability reduces to 50 and $90 \%$ respectively.
\end{abstract}

KEYWORDS: Water resources, agriculture, irrigation.

\section{MODELO HIDROECONÔMICO PARA AVALIAÇÃO DOS IMPACTOS DA ALOCAÇÃO E DISPONIBILIDADE DE RECURSOS HÍDRICOS NA RENDA AGRÍCOLA}

RESUMO: A sub-bacia hidrográfica do rio Buriti Vermelho (BHBV), localizada nas proximidades de Brasília, caracteriza-se por intensa atividade agrícola desenvolvida sob uma distribuição heterogênea de água ao longo do tempo e do espaço. Neswte contexto, o artigo desenvolve um modelo hidro-econômico para quantificação dos impactos de curto-prazo na renda regional agrícola de mudanças nos regimes de precipitação e de disponibilidade de água. O modelo econômico se baseia no método de Programação Matemática Positiva que possibilita a construção de funções de produção agrícolas específicas por cultura e por produtor rural, mesmo para pequenas áreas com poucas observações. Do lado hidrológico, um modelo de naturalização de vazões acoplado a um modelo de balanço de água no solo é utilizado para a estimativa da vazão do rio e dos canais de irrigação. Os modelos econômico e hidrológico são interligados e calibrados com dados primários coletados in situ. Considerando as características hídricas da região, as quais, em anos típicos, garantem uma oferta de água para irrigação nos reservatórios bem acima da demanda, e que culturas irrigadas tem um peso muito maior na composição da receita líquida da região do que culturas de sequeiro, os resultados preliminares indicam que uma redução de $5 \%$ na disponibilidade de água e na precipitação provocaria uma queda de apenas $1,2 \%$ na receita líquida da sub-bacia. Este porcentual, contudo, aumentaria para $11 \%$ e $32 \%$, quando a disponibilidade de água e precipitação se reduzissem para 50 e $90 \%$, respectivamente.

PALAVRAS-CHAVE: Recursos hídricos, agricultura, irrigação.

\footnotetext{
${ }^{1}$ Professor, Dept of Economics, University of Brasília, Brasília

${ }^{2}$ Researcher, EMBRAPA Cerrados

${ }^{3}$ Researcher EMBRAPA Florestas
} 


\section{INTRODUCTION}

Farmers are the dominant water users worldwide, and as part of a resource based system, farmers compete for water resources which are heterogeneously distributed across time and space. Changes in water availability affect agricultural income, productivity and cropping strategies and have potential environmental effects for the hydrologic system as a whole. Therefore, an accurate evaluation of how farmers may react to different water resource policies or environmental scenarios (e.g.: temperature, water supply etc) is important for policy makers and can help to shed light on ways to increase farmers' income and to alleviate poverty in many parts of the rural world. Empirically examining the effects of alternative water allocation regimes on agricultural communities and how farmers' reaction may impact the regional hydrologic system is complex and needs to be interdisciplinary. In fact, several examples of studies that develop models involving economics, hydrology, ecology and agronomy have been developed (Harou et al. 2009). Although all studies represent an effort to integrate different disciplines, each one focuses on a particular issue. For example, Rosegrant et al. (2000), Cai et al. (2003) on salinity and water availability for irrigation; Cai (2008) on the optimal strategies for water allocation among competing sectors and Harou and Lund (2008) on water pricing, irrigation and institutional constraints; Loucks (2006) on the integration of economics and ecology and Guan and Hubacek (2007) on the relationship between economic activity and water quality; and finally Krol et al. (2006), Medellín-Azuara et al. (2008) and Harou et al. (2006) focus on estimations of the impacts of droughts and climate change on water availability for agriculture. While in the cited literature above there are several examples of studies applied to many parts of the world, such as China, California, Spain e Chile to name a few, the only example with an application to Brazil is Krol et al.. Other two more recent studies on Brazil are Maneta et al. (2009), based on pseudo data, and Torres et al. (2012) on the 1995-1996 Ag-Census data. Both studies use a regional agricultural production and revenue model but the latter at the municipio level and the former at the farm level. These different spatial scales imply different hydrological models. The farm scale allows for more sophisticated, fine-tune models, such as the 3D hydrological model MOd-HMS, HydroGeoLogic, Inc. (1996), used in Maneta et al. On the other hand, the larger scale at the município level calls for a courser resolution. As a result, Torres et al. follows the mass-balance model MikeBasin, Danish Hydraulic Institute (2005). In this context, the present study adds to the scarce Brazilian literature on hydroeconomic modeling. It uses an externally coupled hydroeconomic model to estimate and predict the short-run impacts of precipitation cuts on irrigation reservoir levels and the impacts of lower irrigation water supply on farmers' agricultural income. As in Maneta et al., 2009, the focus is on the Buriti Vermelho river sub-basin, situated in the Federal District, near Brasília. The database however is made of primary data collected from interviews performed during the dry and wet seasons of the 2007/2008 agricultural year. More specifically, the economic model uses seasonal observations of outputs and inputs (quantities and prices) per crop from 25 farmers that operate within the subwatershed and farmer, and the hydrological model uses an extensive database on local soil, climate and discharge patterns.

\section{METHODOLOGY}

\section{Economic Component}

The economic model is based on a class of models called Positive Mathematical Programming or PMP, (Howitt 1995) and largely used in applied economics (House, 1987; Howitt and Gardner, 1986; Kasnakoglu and Bauer, 1988; Lance and Miller, 1998; Chatterjee et al, 1998; Paris and Howitt, 1998; Maneta et al 2009, Torres et al. 2012, Howard et al. 2012).

Each farmer $g$ 's goal is to choose $X_{h i}$, the quantity of input $h$ that should be applied on crop $i$ in order to maximize the net income derived from their agricultural activities. More formally ${ }^{4}$,

$$
\underset{X_{h i}}{\max n e t}=\sum_{\mathrm{i}}\left[p_{i} q_{i}\left(X_{h i}\right)-\sum_{h} p_{h} X_{h i}-\left(\alpha_{i} X_{\text {landi }}+0.5 \psi_{i} X_{\text {landi }}^{2}\right)\right] .
$$

\footnotetext{
${ }^{4}$ Subscript $g$ omitted for clarity.
} 
The first term inside the brackets represents gross income where $p_{i}$ is the unitary selling price of crop $i$ which is produced through a production function $q_{i}\left(X_{h i}\right)$, discussed in more detail below. The second term represents total cash costs, in which $p_{h}$ is the price of input $h$. The $h$ inputs considered are land (land), surface water ( $s w$ ), labor (lb), family labor (flabor) and materials (mat). This last category of inputs include the expenditures with fertilizers, pesticides and seeds. The last term (in parenthesis) represents the implicit cost resulting from the allocation of land to a specific crop $i$ and has a quadratic form with parameters $\alpha_{i}$ and $\psi_{i}$. This cost is related to the farmer's land allocation process and is not directly observed by the researcher. Such non-linearity in costs may arise, for example, from managerial constraints, heterogeneity in land quality, spatially non-uniform access to water on farms. The production functions follow a CES (Constant Elasticity of Substitution) functional form and are adapted for rainfed and irrigated conditions. More formally, for rainfed crops, (superscript $r$ ), production is represented by

$$
q_{i}^{r}=A_{i} \operatorname{Precip}_{i}\left(\sum_{h} b_{h i} X_{h i}^{\gamma}\right)^{\frac{\varepsilon_{i}}{\gamma}} .
$$

Where $A_{i}, b_{h i}, \gamma$ and $\varepsilon_{i}$ are parameters. As a rainfed crop, farmers can use all inputs except surface water. So $h$ in (2) represents land, labor, family labor and materials only. The parameter $\gamma$ is defined as $\frac{\sigma-1}{\sigma}$, in which $\sigma$ is the elasticity of input substitution. $\varepsilon_{i}$ is the parameter associated with returns to scale. If equals 1 , greater than 1 or smaller than 1 , we have constant returns, decreasing returns or increasing returns respectively . $\operatorname{Precip}_{i}=\frac{P_{i}^{a}}{P_{i}^{e}}$, where $P_{i}^{e}$ is how much precipitation is expected to fall onto crop $i$ and $P_{i}^{a}$ is the actual amount of precipitation that falls onto crop i.

For irrigated crops (superscript ir) production is represented by

$$
q_{i}^{i r}=A_{i}\left(\sum_{h} b_{h i} X_{h i}^{\gamma}\right)^{\varepsilon_{i}}
$$

Where the arguments and parameters are defined as above, with the difference that famers can now use surface water $(s w)$ and apply it to crop $i$.

Notice that in (3) precipitation affects production only via its effects on the availability of surface water bodies, such as lakes, rivers and man-made reservoirs. This may not be realistic since in many areas of the world, a significant amount of water that are in fact used for irrigation comes from precipitation that falls directly onto the crops, as in the case of the Buriti Vermelho. Since the water bodies store water from previous periods, they are capable, in a given time period, of offering water for irrigation even in the event of a drought. Therefore, if precipitation is lower than expected, farmers may react, ceteris-paribus, by pumping more water from the surface-water bodies to irrigate their crops. That is, precipitation and surface water act as substitute inputs. Therefore, ideally, precipitation level should be included explicitly as an argument of the production function in (3). Due to the lack of time this is not considered in this paper. Future research will properly tackle this issue.

\section{Calibration and Simulation Model}

The parameters of the production function and the land implicit cost term are estimated analytically based on a system of equations implied by the first order conditions for revenue maximization (FOC's) and based on assumptions on the returns to scale and the elasticity of input substitution. The FOC's state that farmers maximize their net revenue by choosing an amount of input applied to crop $i\left(X_{h i}\right)$ such that the value of its marginal marginal product equalizes its economic marginal cost. This economic marginal cost is composed by the sum of the market input price (if the input is traded in a market) and a positive or zero shadow price, in the case of inputs with limited supply. These limiting supply shadow prices may be zero if the restrictions are nonbinding or positive if binding. Fixed supply inputs considered here are land, family labor and surface water.

Besides the market price and the limiting supply shadow price associated with the land input, the PMP approach considers a third component of the economic marginal cost of land. This 
component is the value of the Lagrange multiplier associated with a calibration constraint that restricts the maximum amount of land that can be applied to a given crop to be equal to the amount actually allocated in the base year during which the observed data were collected. This Lagrange multiplier represents in fact an estimation of the marginal implicit cost of land and is set to be equal to derivative of the implicit cost term $\left(\alpha_{i} X_{\text {landi }}+0.5 \psi_{i} X_{\text {landi }}^{2}\right)$ with respect to $X_{\text {landi } i}$. The value of the Lagrange multiplier is crop and farmer specific. All shadow prices and the Lagrange multipliers are calculated through a regional linear programming model of land allocation setup with the mathematical optimization software GAMs.

The additional assumptions on the returns to scale and elasticity of input substitution are required to make the system of equations identifiable. That is we assume that farmers operate under constant returns to scale $\left(\varepsilon_{i}=\varepsilon=1\right)$ and that the elasticity of input substitution $(\sigma)$ is 0.25 . An explicit exercise that shows how the parameters are in fact calculated may be seen in Maneta et al. 2009.

Once the parameters are calculated, their values are re-introduced in (1) and a non-linear regional net revenue maximization problem is set as:

$$
\operatorname{maxnet}_{X_{i h}} \sum_{i}\left[p_{i} \hat{q}_{i}^{r}\left(X_{h i}\right)+p_{i} \hat{q}_{i}^{i r}\left(X_{h i}\right)-\sum_{i} p_{h} X_{h i}-\left(\hat{\alpha}_{i}\left(X_{\text {landi }}\right)+\hat{\psi}_{i}\left(X_{\text {landi }}\right)^{2}\right)\right],
$$

Notice that the sum is over $i$ and $g$ (subscript omitted for clarity) since the model chooses $X_{i h}$ such that the regional net-income is maximized. $\hat{q}_{i}^{r}\left(X_{h i}\right)$ and $\hat{q}_{i}^{i r}\left(X_{h i}\right)$ are respectively the rainfed and irrigation production functions, specified in (2) and (3), and parameterized with $\hat{b}_{h i}$ and $\hat{A}_{i}$, the calculated values of the parameters $b_{h i}$ and $A_{i}$. The estimates $\hat{\alpha}_{i}$ and $\hat{\psi}_{i}$ are the calculated values of the parameters $\alpha_{i}$ and $\psi_{i}$.

This regional maximizatiom problem is subject to the following set of constraints:

$$
\begin{aligned}
\sum_{i} X_{\text {landi }} & \leq B_{\text {land }}, \\
\sum_{i} X_{\text {flabori }} & \leq B_{\text {flabor }}, \\
\sum_{i} X_{s w \mathrm{i}_{m}} & \leq B_{s w_{m}}, \\
\sum_{i} & X_{\text {swim }}=\sum_{i} \operatorname{Met}_{i m} *\left(X_{s w i}\right) .
\end{aligned}
$$

Where, $X_{\text {land } i}, X_{\text {flabori }}$ are respectively the amount of land and family labor applied to crop $i$ by farmer $g . X_{s w i_{m}}$ is the quantity of surface water used in month $m$ to irrigate crop $i$ by farmer $g$. $B_{\text {land }}$ and $B_{\text {flabor }}$ are the maximum quantity of land and family labor available for farmer $g . B_{s w_{m}}$ is the maximum of surface water that can be used by a given farmer $g$ in month $m$ (subscript $g$ is omitted for clarity in (5)).

The last equation in (5) involving the term Met establishes the monthly allocation rule of the annual amount of surface water used for irrigating crop $i, X_{s w i}$. Suppose that a given crop $i$ is planted in January and harvested in April. Suppose also that given the observed level of precipitation and evapotraspiration in these 4 months, irrigation was necessary in March and April only, with 30\% in March and the rest in April. In this case the allocation rule says that the farmer must allocate its intended total annual water to crop $i, X_{i s w}$, accordingly to these percentages.

The model is calibrated when the results from the regional maximizatiom problem formed by equations (4) and (5), in terms of output and input mix for each farmer $g$, approach the mix of outputs and inputs observed by the researcher in the base year. Once calibrated, the model is then used for simulation using non-linear programming techniques with the GAMs mathematical optimization software. 


\section{Modelo hidrológico e de naturalização de vazões}

The Buriti Vermelho River has five small reservoirs, two of which are used for irrigation by the small farmers. Each of the two utilized reservoirs has one canal, which serve different parts of the community. The canal that comes from the first reservoir splits into two by the time it reaches parcels within the community. As the canals are not operated, a model to calculate how much water flows in the canals and how much water each farmer will get was developed. The model simulates discharge in function of the water height above the pipe line. This model was couplet with a hydrologic model, which is based on Thornthwaite and Mather, 1955, procedure (Liebe et al., 2009). Simulations were done daily and the results were aggregated monthly to feed the economic model.

\section{Site of Study, Data and Simulations}

The area of study is the Buriti Vermelho subwatershed, located at about $100 \mathrm{kms}$ of Brasília. The primary data were collected in situ through the application of a survey to all the 25 famers that are located within the basin and that use water from the basin during the agronomical year 2007/2008 (October 2007 through September 2008). The survey was applied in two phases: one right after the wet season (October 2007 - March 2008) and another right after the dry season (April - September of 2008). For each farmer and crops produced during the agronomical year, it was collected data on outputs (prices received and quantity produced) and inputs (prices paid and quantity used). For the setting up of Met $_{i m}$ it was used a planting and harversting calendar for each crop and each farmer plus monthly evapotraspiration data, water demand coeficients for each crop and precipitation data. The database on water used per crop per farmer was built with information collected on the frequency and duration of irrigation, the type of irrigation technology used and the type of pump.

The simulations performed here represent a preliminary effort to demonstrate the analytical capacity of the modeling approach. More specifically, it was simulated a reduction in precipitation of $5,20,50,70,90 \%$ evenly distributed across all the months and estimated its impacts on the monthly water level in the reservoirs and on the farmers' agricultural income.

\section{RESULTS}

The estimates of precipitation and amount of water available for irrigation per farmer per month are given by the hydrological model and used as inputs for Precip $i$ and $B_{s w_{m}}$ in equations (2) and (4) respectively. Figure 1 presents, as a result of the cuts in precipitation and on irrigation water supply, the effects on agricultural income from rainfed and irrigated crops. (Figure 1A ). It is assumed that a cut in precipitation of $\mathrm{X} \%$ induce a reduction in the amount of water in the reservoirs by also $\mathrm{X} \% .^{5}$

As we can see, losses in terms of net income become non-linearly more significant, as reductions in irrigation water availability and precipitation become more accentuated. For example, a reduction of 5\% will induce a loss of $1.1 \%$ in the regional and aggregated (rainfed and irrigated crops combined) net-income. This percentage increases to $11 \%$ and $32 \%$ when the amount of water and precipitation reduce by 50 and $90 \%$ respectively (Figure 1A).

\footnotetext{
${ }^{5}$ A cut of $X \%$ in precipitation in a given period in fact induce a cut on the amount of water available for irrigation in the reservoirs by less than $\mathrm{X} \%$ in that given period since the they store water from previous periods. Hydrological simulated estimates of the actual impact of precipitation on the supply of water in the reservoir are in course and will be subject of future research.
} 


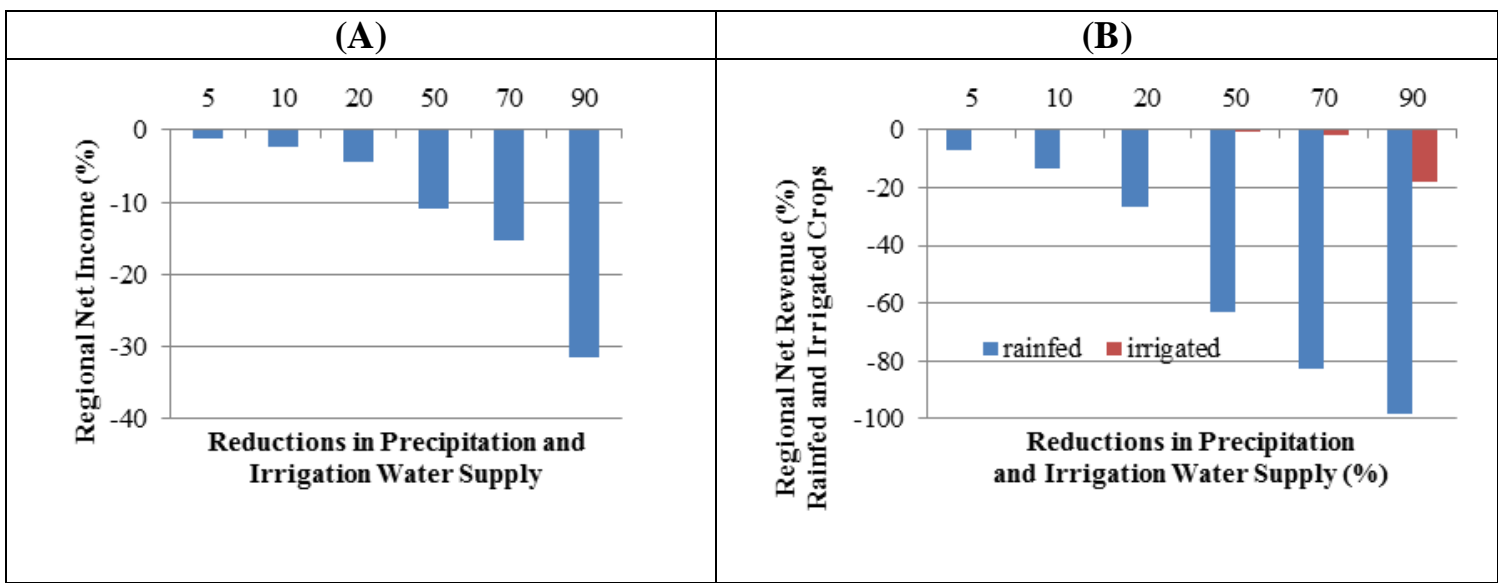

Figure 1 - Reductions in precipitation and irrigation water supply and their impacts on total regional net-income and on the net-income derived from irrigated and rainfed crops.

These may be seen as small considering the significant cuts in precipitation and water supply, but it is important to bear in mind two factors: 1) irrigated crops have a much larger weight on the total agricultural income in the region, and 2) water in the reservoirs only start to become binding and restrictive for irrigated crops when reductions in the irrigation water supply are above $50 \%$ (Figure 1B). In other words, since rainfed crops are more vulnerable to cuts in precipitation than irrigated crops, and given our assumption that precipitation and irrigation water fall in the same proportion, for a given cut in precipitation, losses in profits derived from rainfed crops are much higher than the ones from irrigated crops.

More specifically, in Figure 1B, we see that a 5 to $20 \%$ decrease in precipitation would be followed by a decrease of $7 \%$ to $27 \%$ in the regional net-income derived from rainfed crops and a null effect on net-income based on irrigated crops. This scenario starts to change when cuts in precipitation and in the irrigation water supply are 50\% or more. In fact, a 50\% cut would induce a decrease of 63 and $0,2 \%$ in the regional net-revenue derived from rainfed and irrigated crops respectively. For reductions of $90 \%$, the estimated regional impacts would be of 98 and $18 \%$ for the rainfed and irrigated crops respectively.

\section{CONCLUSION}

Water and precipitation scarcity may have significant and negative impacts on the Buriti Vermelho agricultural net-income. These impacts are more significant for the rainfed crops and as a consequence for the farmers specialized in these crops. Farmers specialized in irrigated crops are also not immune though. In normal years, water in the reservoirs is kept in a sufficient level to irrigate the total area covered by irrigated crops in the region year-round but this may not hold in the event of a drought. In fact, our simulations show that reductions in precipitation and irrigation water supply at $50 \%$ or more, compared to the base-year, would start to affect the net income derived from irrigated crops as well. It is important to highlight however that these effects over the irrigated crops are likely to be subestimated due to the fact that in the present version of the paper, the economic model does not consider the direct effects of a reduction in precipitation on the productivity the crops. Only indirectly via the impacts of precipitation in the amount of water available for irrigation in the reservoirs.

\section{ACKNOWLEDGMENTS}

The presented research was carried out as part of the project "Avaliação de estratégias de irrigação, de opções de alocação de recursos hídricos e de suas consequências econômicas para comunidades rurais: uma abordagem usando modelagem matemática”. We gratefully

\footnotetext{
${ }^{6}$ At $50 \%$, regional net-income from irrigated crops decrease by $0.2 \%$. This is barely seen in the Figure due to scale and style.
} 
acknowledge financial support of Conselho Nacional de Desenvolvimento Científico e Tecnológico (CNPq), Embrapa Cerrados and University of Brasília.

\section{REFERENCES}

Cai, X., McKinney, D.C. and Lasdon, L.S., 2003. Integrated hydrologic-agronomic-economic model for river basin management. Journal of Water Resources Planning and Management, 129(1): 4-17. http://dx.doi.org/10.1061/(ASCE)0733-9496(2003)129:1(4)

Cai, X. (2008), Implementation of holistic water resources-economic optimization models for river basin management: Reflective experiences, Environ. Modell. Software, 23(1), 2 - 18, doi:10.1016/j.envsoft.2007.03.005. http://dx.doi.org/10.1016/j.envsoft.2007.03.005

Chatterjee, B., Howitt, R.E. and Sexton, R.J., 1998. The optimal joint provision of water for irrigation and hydropower. Journal of Environmental Economics and Management, 36(3): 295-313. http://dx.doi.org/10.1006/jeem.1998.1047

Danish Hydraulic Institute (2005), MIKE Basin 2005, User's Guide.

Guan, D. and Hubacek, K., 2007. A new and integrated hydro-economic accounting and analytical framework for water resources: A case study for North China. Journal of Environmental Management, http://dx.doi.org/10.1016/j.jenvman.2007.07.010

doi:10.1016/j.jenvman.2007.07.010.

Harou, J., J. Medellin, T. Zhu, S. Tanaka, J. Lund, S. Stine, M. Jenkins, and M. Olivares (2006), Extreme drought and water supply management in California, paper presented at 2006 World Environmental and Water Resources Congress, Am. Soc. Civ. Eng., Omaha, Nebr., 21- 25 May.

Harou, J. J., and J. R. Lund (2008), Ending groundwater overdraft in hydrologic-economic systems, Hydrogeol. J., 16(6), $1039 \quad-\quad 1055$, doi:10.1007/s10040-008-0300-7. http://dx.doi.org/10.1007/s10040-008-0300-7

Harou, J. J., M. Pulido-Velazquez, D. E. Rosenberg, J. Medellin-Azuara, J. R. Lund, and R. E. Howitt (2009), Hydro-economic models: Concepts,design, applications, and future prospects, J. Hydrol., 375(3-4), 627-643.

Howard, P. H., Goodhue, R., Howwit, R. and P. Mérel. (2012). Are pesticide buffers expensive? Ueing positive mathematical programming to estimate the cost of proposed pesticide buffers in California. Poster presented at the 2012 - AAEA meeting, Seattle.

HydroGeoLogic, Inc. (1996), MODHMS software documentation (v. 3.0), Herndon, Va.

House, R.M., 1987. USMP regional agricultural model. ERS 30, National Economics Division Report, USDA, Washington DC.

Howitt, R.E., 1995. Positive mathematical programming. American Journal of Agricultural Economics, 77(2): 329-342. http://dx.doi.org/10.2307/1243543

Howitt, R.E. and Gardner, B.D., 1986. Cropping production and resource interrelationships among California crops in response to the 1985 Food Security Act, Impacts of farm policy and technical change on US and Californian agriculture Davis, pp. 271-290.

Kasnakoglu, H. and Bauer, S., 1988. Concept and application of an agricultural sector model for policy analysis in Turkey. In: S. Bauer and W. Henrichsmeyer (Editors), Agricultural sector modeling. Wissenschaftsverlag Vauk, Kiel.

Krol, M., Jaeger, A., Bronstert, A. and Guntner, A., 2006. Integrated modelling of climate, water, soil, agricultural and socio-economic processes: A general introduction of the methodology and some exemplary results from the semi-arid north-east of Brazil. Journal of Hydrology, 328(3-4): 417431. http://dx.doi.org/10.1016/j.jhydrol.2005.12.021

Lance, H.L. and Miller, D.J., 1998. Estimation of multioutput production functions with incomplete data: a generalized maximum entropy approach. European Review of Agricultural Economics, 25: 188-209. http://dx.doi.org/10.1093/erae/25.2.188

Liebe, J.; van de Giesen, N.; Andreini, M. S.; Walter, M. T.; Steenhuis, T. Determining watershed response in data poor environments with remotely sensed small reservoirs as runoff gauges. Water Resources Research, v.45, p.W07410, 2009. http://dx.doi.org/10.1029/2008WR007369

Loucks, D. P. (2006), Modeling and managing the interactions between hydrology, ecology and economics, J. Hydrol., 328(3 - 4), 408 - 416. http://dx.doi.org/10.1016/j.jhydrol.2005.12.020 
Maneta, M.; Torres, M. ; Wallender, W. ; Vosti, S. ; Howitt, R. ; Rodrigues, L. ; Bassoi, L. . A spatially distributed hydro-economic model to assess the effects of drought on land use, farm profits, and agricultural employment. Water Resources Research, v. 45, p. w11412, 2009. http://dx.doi.org/10.1029/2008WR007534

Medellín-Azuara, J., J. J. Harou, M. A. Olivares, K. Madani, J. R. Lund, R. E. Howitt, S. K. Tanaka, and M. W. Jenkins (2008), Adaptability and adaptations of California's water supply system to dry climate warming, Clim. Change, 87, suppl. 1, S75- S90. http://dx.doi.org/10.1007/s10584-0079355-Z

Paris, Q. and Howitt, R.E., 1998. An analysis of ill-posed production problems using maximum entropy. American Journal of Agricultural Economics, 80: 124-138. http://dx.doi.org/10.2307/3180275

Rosegrant, M. W., C. Ringler, D. C. McKinney, X. Cai, A. Keller, and G. Donoso, 2000. Integrated economic-hydrologic water modeling at the basin scale: the Maipo river basin. Agricultural economics, 24(1): 33-46.

Torres, M.; Maneta, Marco ; Howitt, Richard ; Vosti, Stephen A. ; Wallender, Wesley W.; Bassoi, Luís H. ; Rodrigues, Lineu N., 2012 . Economic impacts of regional water scarcity in the São Francisco River Basin, Brazil: an application of a linked hydro-economic model. Environment and Development Economics, 17: 227-248. http://dx.doi.org/10.1017/S1355770X11000362

Thornthwaite, C. W., and J. R. Mather (1955), The water balance, Publ. Climatol., 8(1), 1 - 104. 